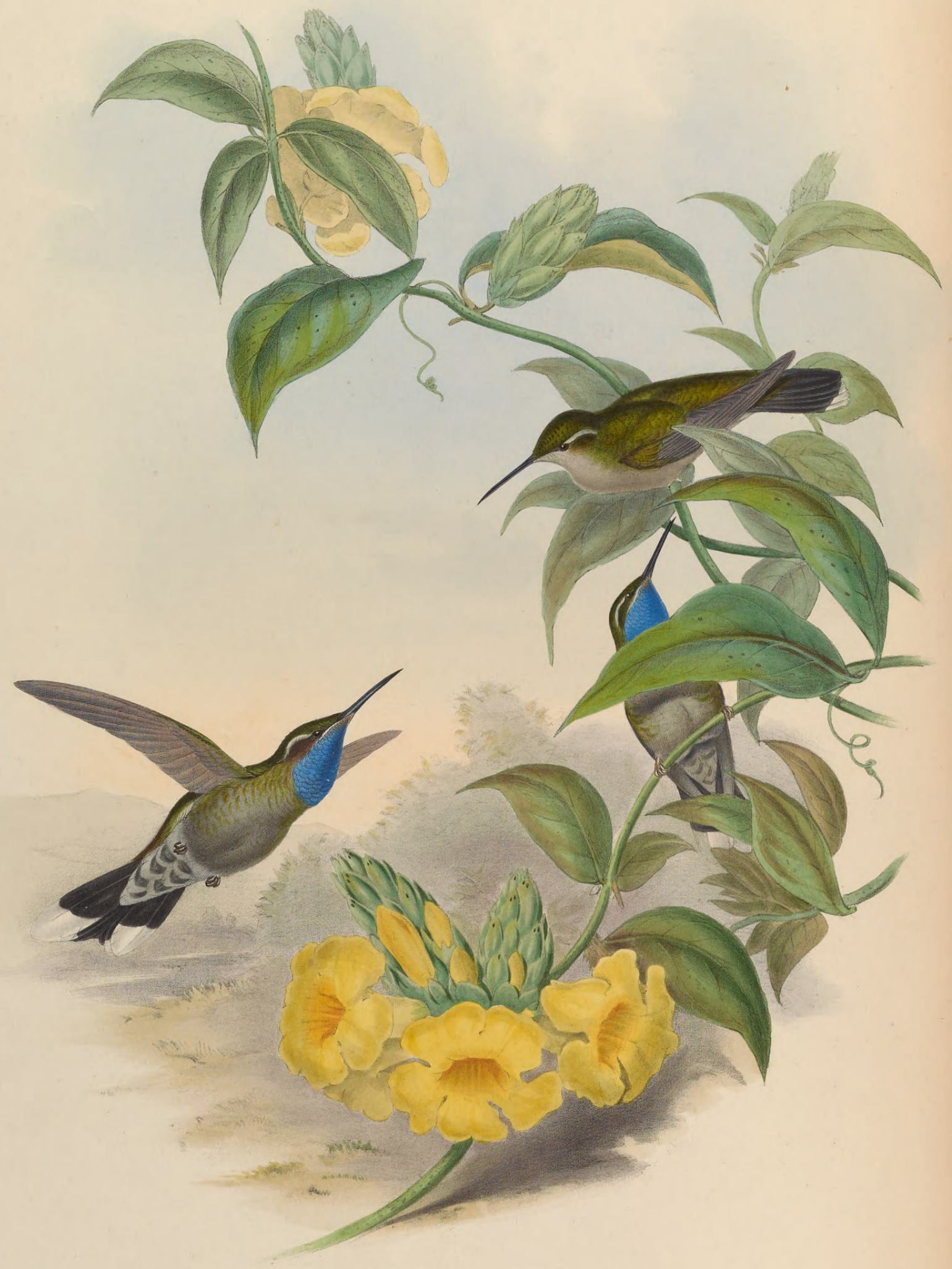

$\mathbb{D E} I A T T R I A \quad C L \mathbb{M} \mathbb{A} \mathbb{N} \mathbb{C} I \mathbb{E}$. 


\section{DELATTRIA CLEMENCIAE.}

\section{Blue-throated Cazique.}

Ornismya Clemencia, Less. Hist. Nat. des Ois. mou., pp. xlv et 216. pl. 80.-Ib. Supp. des Ois. mou., p. 115. pl. 8.

Lampornis Clemencia, Less. Traité d'Orn., p. 279.

Coligena Clemencia, Less. Ind. Gen. et Syn. des Ois. du Genre Trochilus, p. xviii

Mellisuga Clemencia, Gray and Mitch. Gen. of Birds, vol. i. p. 112, Mellisuga, sp. 16.

Delattria clemenciae, Bonap. Consp. Gen. Av., p. 70, Delattria, sp. 3.

Lampornis clemencia, Bonap. Rev. et Mag. de Zool. 1854, p. 250.

Coeligena Clemenciae, Reichenb. Aufz. der Colibris, p. 7.

I BeLIeve the true and restricted habitat of Delattria Clemencice to be the moderately high table-land of Mexico. It is a large and powerful bird, and is distinguished for the quietness of its colouring, rather than for any of those brilliant metallic markings so prevalent among Humming Birds in general. M. Lesson has figured both sexes in his volumes on this group of birds, but unfortunately has not given any details as to their habits and economy ; this omission is the more to be regretted as it leaves me in doubt as to the propriety of placing the bird in the genus Delattria ; for, although it has not their broad shafted primaries, in its general colour and markings it approaches so closely to the members of the genus Campylopterus, that it becomes a question to which of the two groups it should be referred; future research, then, must determine its true situation.

The sexes differ in the blue throat-mark of the male being entirely wanting in the opposite sex.

The male has the crown of the head, all the upper surface, wing-coverts and flanks dull golden green, changing into bronzy brown on the lower part of the back; behind the eye a semi-crescentic mark of white; throat beautiful azure-blue; under surface ashy grey; under tail-coverts greenish grey, bordered with white; wings purplish brown; upper tail-coverts and tail purplish black, the two lateral feathers on each side largely tipped with white; bill brownish black; feet brown.

The female is very similar in colour to the male, but has no blue on the throat, that part, like the under surface, being grey.

The figures represent two males and a female, of the size of life. The plant is the Adenocalymna comosum. 


\section{$2 \mathrm{BHL}$ Biodiversity Heritage Library}

Gould, John. 1852. "Delattria clemenciæ, Blue-throated Cazique. [PI. 60]." A monograph of the Trochilidae, or family of humming-birds 2, https://doi.org/10.5962/p.316869.

View This Item Online: https://www.biodiversitylibrary.org/item/108332

DOI: https://doi.org/10.5962/p.316869

Permalink: https://www.biodiversitylibrary.org/partpdf/316869

\section{Holding Institution}

Smithsonian Libraries

\section{Sponsored by}

Smithsonian Institution Libraries

\section{Copyright \& Reuse}

Copyright Status: NOT_IN_COPYRIGHT

This document was created from content at the Biodiversity Heritage Library, the world's largest open access digital library for biodiversity literature and archives. Visit BHL at https://www.biodiversitylibrary.org. 